\title{
Sequence Stratigraphy towards its standardization-an important scientific scheme
}

\author{
WuHeyuan ${ }^{1,2 *}$, Muneeb Khan ${ }^{1}$, Song Ping ${ }^{1}$ \\ ${ }^{1}$ School of Earth Sciences and Engineering, Xi'an Shiyou University, Xi' an, Shaanxi, 710065, China \\ ${ }^{2}$ Shannxi Key Laboratory of Petroleum Accumulation Geology, Xi' an Shiyou University, Xi' an Shaanxi, 710065, China
}

\begin{abstract}
In the Post-Exxon Era of sequence stratigraphy, various sequence models for the complex stratigraphic records with their response mechanisms are developed. All the models with strong pertinence are endowed, which lead to misapprehension in the conceptual system. Therefore, the standardization of sequence stratigraphy with the aim to provide consistency in the terminology has become an important motive of modern sequence. During the development of sequence stratigraphy, the identification and distinction between normal and forced regression have laid important foundation for the system description of sequence development. This becomes the first step towards the standardization because of modelindependent nature. The introduction of model-independent unconventional system tracts in fluvial sequence models, which are low- and high-accommodation system tracts, which turn out to be another successful attempt of towards the standardization of sequence stratigraphy. The four parts of stratigraphic records, which include the complexity and cyclicity in the stratigraphic accumulation process; the nongradual change and the non-integrity of the stratigraphic records; the variability represented by the diversity of the sequence models and the nature of standardization including variability, will provide more clues and approaches for further sequence stratigraphy development
\end{abstract}

\section{Introduction}

The Sequence stratigraphy was introduced into the mainstream of stratigraphic practice in the 26 seismic stratigraphic compilations by American Association of Petroleum Geoscientists [1]. Special Publication (42) of the Society for Sedimentary Geology (Wilgus et al., 1988) has improved the conceptual system and working methods of sequence stratigraphy to make it more systematic and convenient [2-4]. Thus this time frame (1977 to 1988) is also known as the Exxon era of sequence stratigraphy [5-7]. In Transgressive-Regressive model, the maximum flooding surface was considered as sequence boundary [8]. The conceptual system of the Exxon schools, the Trangressive-Regressive sequences $[9,10]$ and the drowned unconformity sequence [11] were proposed in order to recognise and correct the absurd sequence stratigraphy. Similarly, the domestic scholars have further explained and developed the mechanism of sequence formation [12], the sequence boundary [13]and the high-resolution sequence stratigraphy $[14,15]$. These are some important results achieved through in-depth exploration and research of complex stratigraphic records and their response mechanism, thus, the sequence stratigraphy enters the post-Exxon era with diverse models. In this era, there are often more conceptual chaos and incongruous conceptual systems. The standardization of sequence stratigraphy therefore becomes an important scientific topic in the research of sequence stratigraphy. Therefore, in order to further pursue the scientific connotation, in depth understanding of the earlier work about complex stratigraphic succession and the response mechanism is important. At the same time, it might play a role for the stimulus effect and is beneficial to the further development of sequence stratigraphy.

\section{Recognition and correction of an incongruous conceptual system of the Exxon sequence model}

The concept of Sedimentary sequence is introduced by Vail et al. [16] and daringly interpreted the sedimentary sequence as a result of change in sea-level cycle. On the basis of such sea level fluctuation, the Exxon schools proposed two types of sequence models, including type I and II sequences. However, there is an incongruous conceptual system[17] : (1) the Exxon sequence pattern puts the sedimentation of the basin flank during sea-level decline under the sequence boundary, and conversely, puts the area near the basin above the sequence boundary; (2) the bottom boundary of the type I sequence in the "sedimentary sequence" model is defined by the inflection point of the sea-level fall (Fig. 1), the bottom boundary of the type II sequence is placed at the lowest point of sea-level change, and two types of high stand system tract (HST) are formed; (3) when plotting the

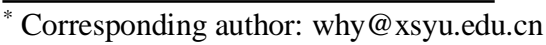


sea-level change curve with time as the ordinate, the Exxon scientists consciously place the sequence boundary at the lowest point of the sea-level change, which causes the incongruous conceptual system of the Exxon sequence model[18,19] and triggers the fierce debate of comparable conformity locations in the sealevel change curve.

Among all modified schemes proposed by sequence stratigraphers, including the incongruous conceptual system of the Exxon sequence model, the proposals of Hunt \& Tucker [20] and Posamentier \& Allen [21] are the most conspicuous (Fig. 1). However, these two proposals have qualitative differences in the description of the sedimentary trend change. At the same time, Hunt \& Tucker (1992) proposed a concept of the forced regressive wedge systems tract (FRWST) to avoid distinguish of shelf sediments and deep-water sediments in the sea-level fall stage which emphasizes that there is an incongruous conceptual system in the Exxon sequence model. FRWST is defined as the sediment of the base-level fall at the lowest points in the forced regressive stage, and the lowest point of the sea-level change is considered as the comparable conformity (CC;[22]; Fig.1). All sediments of the lowest points of sea-level change are placed above the sequence boundary, and the four parts of the sea-level change curve are recognized. In addition, the argument about the relative sea-level fall stage and the low-level stage in the early pattern is resolved.

In contrast to Hunt \& Tucker (1992), Posamentier \& Allen's (1999) considers the beginning of the base-level fall as $\mathrm{CC}$ is more redundant. By moving up the type I sequence boundary to the beginning of the base-level fall and cancelling type I and II of the Exxon sequence model, three definitions (Lowstand system tract (LST), Transgressive system tract (TST), and Highstand System Tract (HST)) of the Exxon sequence model are developed. However, when considering the Middle Cenozoic global sea-level change curve[17], the Jurassic global sea-level change curve[18] and the Triassic global sea-level change curve [19], the revised method of placing CC at the highest point of the base level[21] not only fails to resolve the incongruous conceptual system, but also makes it more prominent. Thus, the quartered system tract revision which places the sequence boundary at the lowest point of the base level [20] shows some advantages. The superiority of the system is recognized by sequence stratigraphers. It provides an important basis for the subsequent sequence stratigraphy standardization.

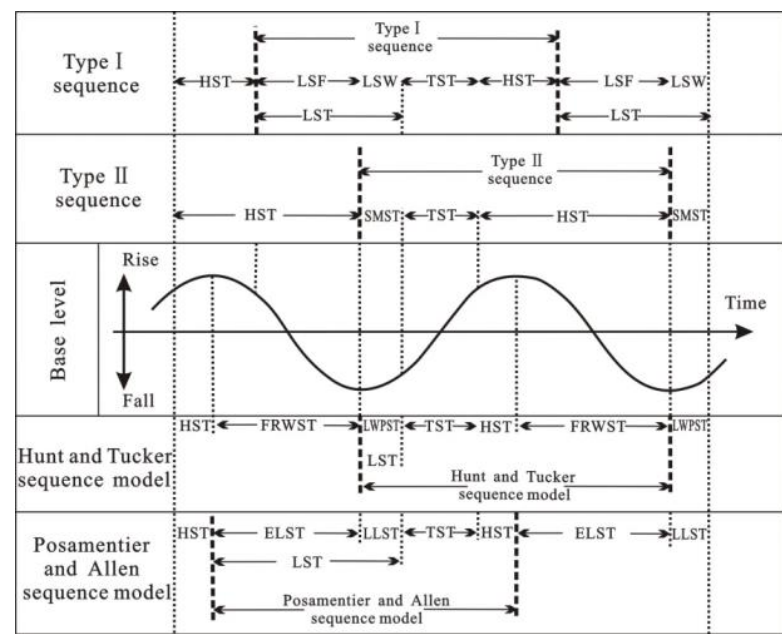

Fig.1 Two types of modification of the inconsistencies in the conceptual system of the Exxon sequence models.

The fuzzy limitation of two types of high stand system tract and system tract boundaries is extensively discussed by sequence stratigraphers in the type I and II Exxon sequence models. Aiming at the incongruous conceptual system, Hunt and Tucker (1992) divide the up-and-down cycle of the sequence formulation into four parts while placing the correlative conformity at the lowest point of the base-level curve. These four parts correspond to four types of system tracts (HST +LWPST + TST + FRWST). In contrast, Posamentier and Allen (1999) placed the sequence boundary at the highest point of the base-level change curve, and three systems tracts (LST, TST and HST) of the Exxon sequence model are developed.

\section{Description of the transgressive \& regressive processes of the sequence- an odd attempt towards standardization}

In the Post-Exxon Era, the various divisions of system tracts and analyses of the base-level change curve are established and diverse sequence models are constantly emerged. From the bold hypothesis of the Exxon type I and II sequence boundary locations of the sea-level change curve to the "trisection" or "dichotomy" of the Post-Exxon Era system tract and the precise definition of every sequence boundary location in the base-level change curve, the base-level change curve is still feasible for interpreting the change of the depositional trend. The changes in the depositional trend and base-level cycle are preferred (Fig. 1) until the emergence of another type of system tract.

Helland-Hansen [23] highly agrees on correction of the incongruous conceptual system of Hunt and Tucker's [20]. While placing the sequence boundary at the lowest point of the base-level change curve, the up-and-down cycle of the base level should include transgressive and regressive stages. The four types of system tracts in the stratigraphic succession are developed under the effect of both base-level change and sediment supply[24] (Fig. 2): (1) Lowstand wedge system tract (LSWST) which is from the lowest point of the sea level to the maximum location of regression during the period of relative sea- 
level rise, (2) transgressive system tract which is from the maximum regression to the maximum transgression during the period of relative sea-level rise, (3) highstand system tract which is from the maximum transgression to the next relative sea-level drop during the period of relative sea-level rise, and (4) forced regressive system tract which is from the beginning to the end of the relative sea-level drop during the period of relative sealevel drop. Based on this, the quartered system tract is formed.

Based on the rate of shoreline deposition and baselevel rise, three types of depositional progresses are further divided [25-27] (Fig. 2). The first type is the normal regression, it shows a progradation process with the aggradation characteristic; if the shoreline deposition rate is greater than the base-level rise rate, the progradation process is driven by sediment supply. According to its location on the base-level curve, it can be further divided into LNR and HNR [28-30]. The second type is the transgressive deposition; it is a continuous retrogradation process due to the base-level rise rate greater than the deposition rate during the baselevel rise. The third type is the forced regressive deposition [31], it is a progradation process driven by the base-level drop of the shoreline and has no relationship with the change of the sediment supply rate. The shoreline area is forced to regress, forming a stepwise progradation process during the base-level drop. The four stages corresponding to the complete base-level change cycle are then formed: normal regression stage driven by sediment (LNR and HNR), transgression stage (TS) and forced regression stage driven by base-level drop (FR). Corresponding to three regressions and one transgression, there are four types of system tracts: lowstand normal regressive systems tract, transgressive systems tract, highstand normal regressive system tract and forced regressive system tract. The form and concept of every system tract are independent of the sequence stratigraphic model.

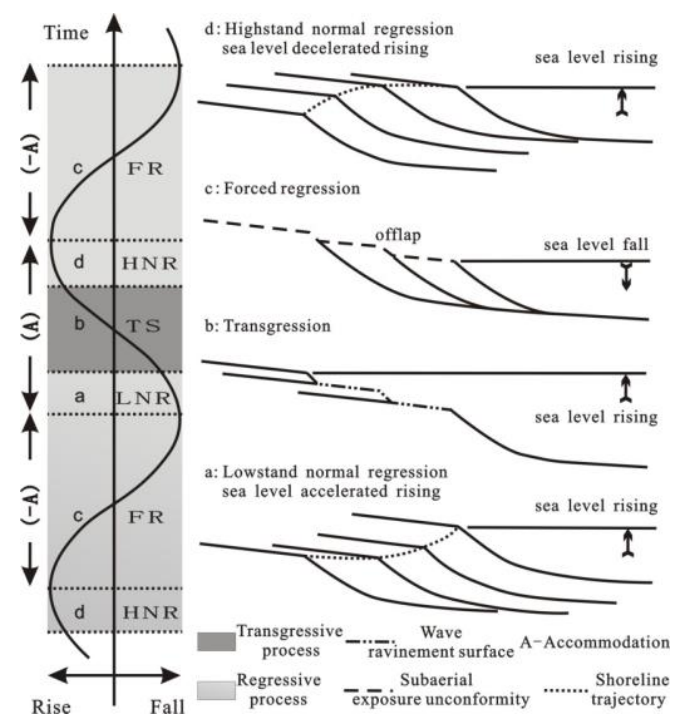

Fig. 2 Change of the main sedimentary processes and depositional trends within a rise and fall of cycle at the base level.
The up-and-down cycle of a base-level change includes two main processes: transgression and regression. According to the relative magnitudes of the base-level change and deposition rates, it can be divided into three "regressions" and one "transgression", which are the lowstand normal regression (LNR), transgression (TS), highstand normal regression (HNR) and forced regression (FR) respectively. Among them, LNR is a concave shoreline trajectory in the stage of accelerated base-level rise due to change of the depositional trend from pro-gradation to aggradation, and HNR is a convex shoreline trajectory in the stage of decelerated base-level rise due to change of the depositional trends from aggradation to progradation.

Based on the different sedimentary environments, diverse sequence models are developed from different groups of system tracts in the Post-Exxon Era (Fig. 3): (1) connecting the sediments between two correlative conformities at the lowest point of the sea-level curve (corresponding to Hunt and Tucker's sequence model [20]; (2) connecting the sediments between two maximum regressive surfaces (corresponding to the " $\mathrm{T}-$ R" cycle of Johnson et al.[32] and the "T-R sequence" of Embry and Johannessen[9]; (3) connecting the sediments between two maximum flooding surfaces (corresponding to the "genetic sequence" of Galloway [8]); (4) connecting the sediments between two correlative conformities at the highest point of the sea-level curve (corresponding to Posamentier and Allen's sequence model (Posamentier and Allen, 1999); (5) connecting the sediments between two exposure unconformities (and their correlative conformity) during the period of relative sea-level drop (corresponding to the type I and II "depositional sequence" of Vail et al. (1984)); and (6) the drowned unconformity sequence applied to the carbonate environment (CS+HST; Goldhammer 1990; Mingxiang, 1996; Schlager, 1999). Every sequence model has the characteristics of the corresponding depositional trend. The large variability of the stratigraphic boundary and system tract due to the unique factors controlling the sedimentary environment makes all models relevant. However, not every model is invariable; the sequence stratigraphy is variable during the formation of the stratigraphic sequence.

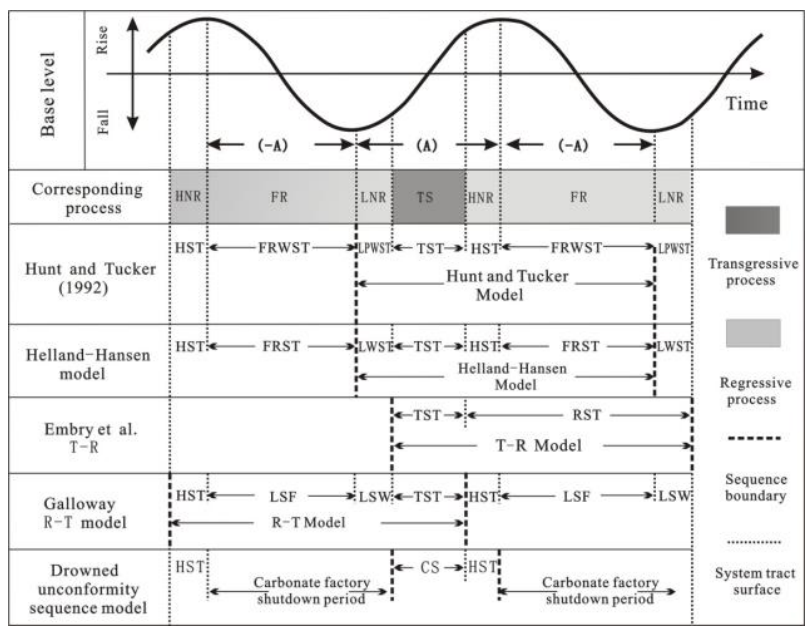

Fig. 3 The main sequence models in the post-Exxon Era. 
A-accommodation; TS-transgress; FR-forced regress; RSTregressive system tract; LPWST-lowstand progressive wedge system tract; FRWST-forced regressive wedge system tract; LST-lowstand system tract; HST-highstand system tract; TSTtransgressive system tract; FRST-forced regressive system tract; ELST-early lowstand system tract; LLST-later lowstand system tract; LSF-lowstand fan; LSW-lowstand wedge

Taking the maximum flooding surface as an example [8,33-34], the transitional surface from the transgression to the high stand normal regression of the shoreline is formed in the period of base-level rise. The conversion from the retro-gradation to the pro-gradation of the shoreline indicates the end of the transgression. The maximum flooding surface may be accompanied by the formation of a transgressive ravinement surface in the clastic sedimentary environment. During the period of transgression, the landwards migration of the shoreline trajectory may lead to erosion to the lowstand normal regression, forced regression, and even the highstand normal regressive sedimentary system, which covers de the transgressive system tract and all earlier types of deposition. Cycles B and C can be reasonably defined by application of the maximum regressive surface and transgressive ravinement surface in the stratigraphic cyclic accumulation sequence (Fig. 4). The exposed surface (unconformity) indicates the birth of sequence stratigraphy, and its conservation potential is mainly controlled by both the depth of the transgressive erosion and the aggradation during the transgression period. In addition, this surface may be covered by the lowstand normal regression (Fig. 4). If part of this surface is replaced by a transgressive ravinement surface [35-37], cycle $\mathrm{C}$ may be synthetically depicted by both the exposure unconformity (and its correlative conformity) and transgressive ravinement surface. Additionally, when the evidence of exposure unconformity is completely destroyed, it is difficult to distinguish the real unit limited by unconformity from the superimposed parasequence. When the sediment supply is sufficient, identifiable signs among the highstand normal regressive system tract, forced regressive system tract and lowstand normal regressive system tract are absent. At this time, the dichotomy system tract is more appropriate than the quartered one, namely the transgressive system tract and the regressive system tract, corresponding to the " $\mathrm{T}-\mathrm{R}$ sequence".

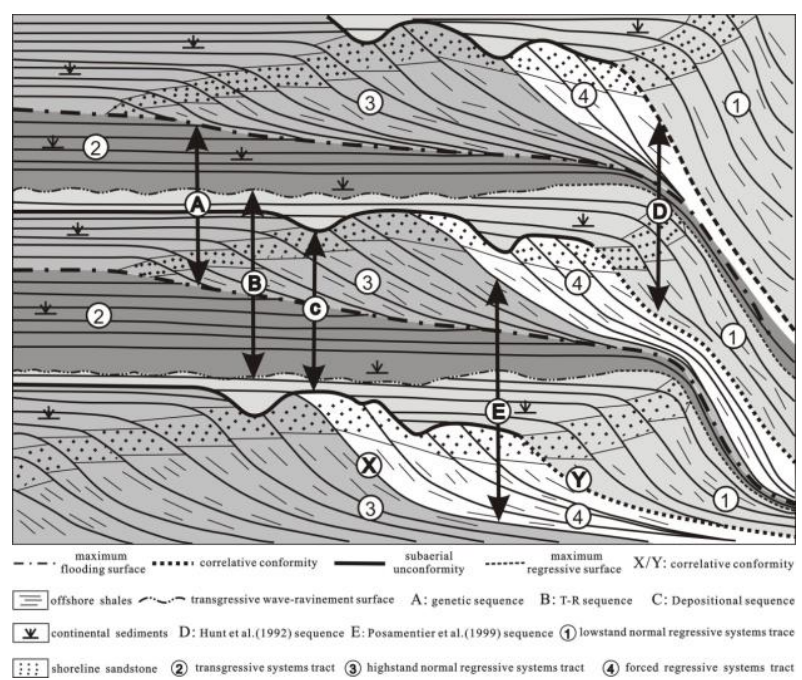

Fig. 4 Four sequence formation processes and superimposed relationship of the system tracts (modified after HellandHansen and Gjelberg[23])

In combination with different stratigraphic boundaries, the complete base-level change cycle is described. Selection of the modular method of different system tracts leads to various sequence models in the cyclic stacking sequence. In the framework of cyclic stratigraphy, the system tract presents different horizontal distribution states and is superimposed orderly in the vertical. Due to the interaction of the sea-level change and sediment supply rates, the lowstand and highstand normal regressive system tracts have no fixed position during the relative sea-level rise. The transgressive ravinement surface accompanied by the maximum flooding surface may lead to transgressive systems tract and there with all earlier types of system tracts. Moreover, with the exposure unconformity in the forced regression stage, the extension range extends to the sea, and lately, the preservation degree is strongly variable.

The variability of sequence stratigraphy during the formation of the stratigraphic boundary and system tract not only explains the complexity of the stratigraphic records but also provides substantial evidence for the argument that no single sequence model can be applied to all sedimentary stratigraphic sequences. A sequence stratigraphic method covering all sequence models cannot be found; however, this does not mean that there is no complete agreement among diverse sequence models because all stratigraphic sequences have common basic building modules (system tracts), as emphasized by Catuneanu et al. [38]. The identification of these building modules is more important than the choice of the sequence model and is also the basic premise to reach consensus in sequence stratigraphy.

The recognition of four processes [23] represents an intelligent way of understanding the change of the depositional trend. It emphasizes the identification of the sequence boundary, the change of the sedimentary facies and the transformation of the stratigraphic geometrical morphology. The stratigraphic progradation, retrogradation, aggradation and downcutting reflect the attributes of sedimentology and sequence stratigraphy through the combined effect of both sedimentation and 
base-level change rates. The depositional trend change reflected by the four processes in the base-level curve and the formation of the sequence boundary are core concepts, which are independent of diversified sequence stratigraphic models, and are not only the main content of sequence stratigraphy research but also the basis of sequence stratigraphy "standardization". If the quartered system tract of Helland-Hansen[23] is considered as the tentative exploration of the standardization of sequence stratigraphy, the detailed description of the transgression-regression process through the distinction of normal and forced regression would provide the most satisfactory solution for the ideal base-level change cycle and system tract division, because the segmentation of its concept not only refines the manifestation of the sedimentary trend in the base-level change curve, but also emphasizes the importance of sedimentary trend research. It is the first important intelligent attempt towards the standardization of sequence stratigraphy.

\section{Introduction of the concept of unconventional system tract in the fluvial sequence-the second important tremendous attempt towards standardization}

The standardization of sequence stratigraphy requires consent among all sequence models, which means consistency of concept and terminology. Facing the different sedimentary environments, the microadjustment to the sequence definition of Catuneanu et al.[38] and Catuneanu [39] pays more attention to the common cycles of accommodation and change in sediment supply which broadens the application of sequence stratigraphy to all sedimentary environments and ultimately introduces the unconventional system tract concept in the fluvial facies sequence.

During continuous maturing of sequence stratigraphy in the Post-Exxon Era, the application of unconformity to river alluvial architecture interpretation [40-43] make the concept of sequence stratigraphy into the stage of fluvial sedimentary sequence interpretation. Aiming at the control factors of tectonic movement, sea-level and climate change in near-shore fluvial sedimentary environments of passive continental margins, the direct control of the sea-level change in the river sediment and the approximate equivalence of base-level and relative sea-level change [44] are emphasized. A series of fluvial facies sequence models are established using the quartered system tract (LST, TST, HST, RST) for the asymmetric definition of the marine facies. Among them, the fluvial facies sequence model proposed by Wright and Marriott's [42] and Shanley and McCabe's [41] (Fig. 5 ), and theoretical breakthroughs $[43,45]$ are made to provide important methodological approaches for interpretation of the fluvial sedimentary sequence. The definition of the fluvial facies system tract boundary is still the weak definition of the Exxon era, and the location of the system tract and sequence boundary are not precisely defined. But the concept of the sequence boundary forming in the base-level drop period reflects the important progress in the research of fluvial facies sequences.

The sequence of the coastal environment of the fluvial facies is limited during the base-level rise using the distinction of normal and forced regression [38-39]. The amalgamated fluvial channel deposits in the lowstand normal regressive period and the filling successions from transgressive floodplain-isolated fluvial deposits to highstand normal regressive amalgamated fluvial channel deposits are formed (Fig. 5). It summarizes coastal rivers sequence research. However, the "conventional system tract" is formed from the marine facies quartered system tract. The close connection of shoreline trajectory change, as well as the dominance of the tectonic movement and climate change to sediments in inland environments, makes the "conventional system tract" confined near the shoreline only. The unique preservation of the inland river fossils, the rapid lateral transformation of the sequence and the difficult identification of the sequence boundary are precursors for the introduction of the "unconventional system tract" concept, which is independent of the sequence model.

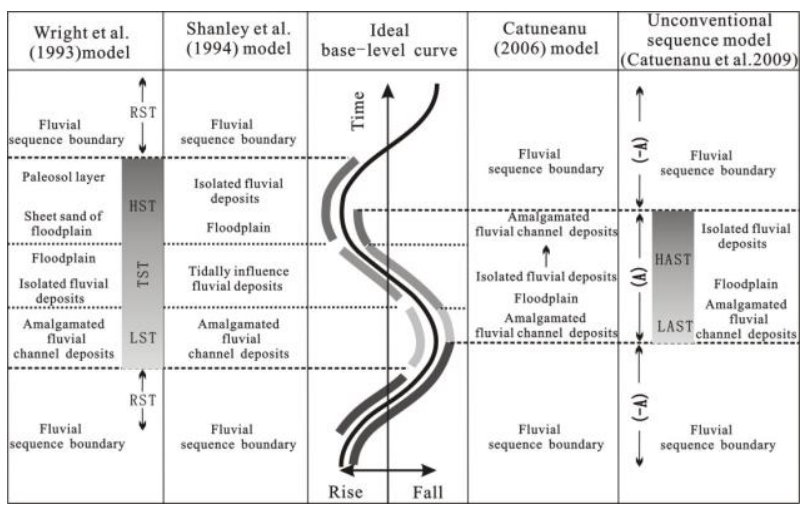

Fig. 5 Comparison of main river sequence models

In the Post-Exxon Era, the fluvial system tract boundary follows the weak definition of the Exxon era, the boundary putting at the inflection point of the baselevel drop until the fluvial sequence boundary is at the lowest point of the base-level curve. However, the fluvial sequence model characterized by the marine facies quartered system tract (LST+TST+HST+RST) is only limited to near-shore fluvial sedimentary environments. The fluvial sequence model developed by the "unconventional system tract" (LAST + HAST) brings the sequence stratigraphy into the inland fluvial sedimentary systems.

The "unconventional system tract", an objective explanation of the complex geological record in inland sedimentary environments, refers to the system tract type related to special fluvial sedimentary environments with the exception of the conventional system tract [46]. According to the ratio of different sedimentary components in the stratigraphic succession, it can be described as "low accommodation system tract" (LAST) and "high accommodation system tract" (HAST; Fig. 5). The emphasis is on the joint control of both accommodation and sediment supply in the process of 
fluvial sequence formation; the base-level change process is reflected by the sediment thickness of the vertical superposition in the stratigraphic record [47]. The important difference relative to the conventional system tract is that the unconventional system tract suggests that the sedimentary strata are deposited during the base-level rise period (positive accommodation) in a whole fluvial sedimentary sequence and the sequence boundary is formed in the base-level drop period (negative accommodation). The system tract is simply defined by the ratio of the river stratigraphic framework unit affecting amalgamated fluvial channel deposits on behalf of the sedimentation in the low-accommodation stage, and the flood plain sediment with isolated fluvial deposits representing the sedimentation of the highaccommodation stage; lakes and more coal beds are developed during this stage. Based on these cognitions, the fluvial deposition and its related sedimentation are classified into low- and high-accommodation system tract. This interpretation is based on the sedimentology which is independent of the model, and its flexibility of application is widely accepted by geologists [48-49]. However, compared with the marine facies, the more complicated variability of the fluvial facies stratigraphic sequence shows that the unconventional system tract stratigraphic model also cannot be applied to all fluvial stratigraphic successions.

Taking the Upper Triassic Xujiahe Formation of the Sichuan Basin as an example, there is major concern by domestic stratigraphers because of six characteristic lithologic members in the coal-bearing strata [50-52]. Among them, the first, third and fifth members are coalbearing fine-grained clastic fluvial strata of high accommodation, and the second, fourth and sixth members are sandy bottom-loading high-energy fluvial sediments of low accommodation [53]. According to the cyclicity reflected by the rock stratigraphic classification and sedimentary sequence, the Xujiahe Formation is divided into three fluvial facies sedimentary sequences. However, the overall upward-coarsening alluvial architecture creates a huge contrast with the current fluvial facies sequence model (compared to Fig.5). It is difficult to describe and analyze the variability of the stratigraphic succession with the current sequence model, but the objective accommodation change process is common to all fluvial facies stratigraphic successions and independent of the sequence model. Therefore, to standardize sequence stratigraphy, the introduction of the unconventional system tract concept diminishes limitations of fluvial sequence research in the coastal environment. Extending the sequence stratigraphic concepts to the inland fluvial sediments leads to a breakthrough in the sequence research of inland lakes, swamps and deep-sea sedimentary systems, and is important for development of sequence stratigraphy. The more prominent contribution is that the introduction of the concept of the unconventional system tract provides confirming terms for the sequence stratigraphic standardization of all inland sedimentary environments, and it is another successful attempt of sequence stratigraphy standardization.

\section{Discussion}

As an effective tool of local and regional stratigraphic correlation, the sequence stratigraphy broadly conducive to geologists although it is still not consolidate into any stratigraphic code or standard procedure. In the PostExxon Era of model diversity, the sequence stratigraphers seek a concept and method which can camouflage all sequence models, but the unified consensus was a day dream. In 2009, headed by Catunenau, 28 scientists put forward the concept of "towards the standardization of sequence stratigraphy", and relentless discussion about the standardization of sequence stratigraphy has initiated. However, the comprehensive "standardization" concept and the interrelation of "standardization" and "variability" in the standardization process are still fuzzy in many sequence stratigraphic practices.

On the basis of different observation levels and available data types, different sequence models are applied to describe and analyze stratigraphic succession. However, no matter what type of difference exists among the stratigraphic succession, these are the product formed by the combined action of both accommodation and sediment supply, and are formed from the combination of different types of system tracts or genetic units. The purpose to clearly define the "standardization" of sequence stratigraphy is to explore the common basis of all models and to seek consistency of concept and term among diversified sequence models through the basic concept, which is independent of the model [39]. At the same time, continuing practice of sequence stratigraphy realizes that each sequence model is closely related to its unique geological background [3,8,23,5456]. The diversification of the sequence model, the intense complexity of the sequence boundary and system tract is the direct effects of the variability of sequence stratigraphy. Therefore, considering the complexity of the stratigraphic record and the variability of the controlling factors in the sedimentary environment, the use of each sequence model should be combined with the actual geological background.

Twenty-eight scientists, including Catunenau, discussed "standardization" points for the further development of sequence stratigraphy. The sequence stratigraphic work process which is independent of the model; not only provides possibilities for standardization, but also supports the identification. The "quartered" system tract and the ideal base-level change curve provide tailed comparison tools for interpretation of all types of sequence-superposed styles and genetic units as well as main carriers for the standardization of terms. The introduction of the unconventional system tract provides a breakthrough in the research of continental fluvial sequences. These important attempts of standardization are symbols of the increasing maturity in the field of sequence stratigraphy. Although these concepts are affirmed, it is independent of the models; the eternal characteristics of the standardization process and the variability of sequence stratigraphy should also be valued. When we constantly praise all types of sequence models, some phenomenon which is difficult to 
explain by current sequence models can always be observed in the stratigraphic succession. The standardization of sequence stratigraphy is the process to seek "consistency" in "variability". The two contradictory characteristics have the common purpose of studying the change of depositional trends in complex stratigraphic record and explore more consistency, these two are contradictory. The sequence stratigraphy cannot discuss "consistency" apart from "variability", and on the contrary, the "variability" of sequence stratigraphy examines the progress of the standardization of sequence stratigraphy to some extent. Furthermore, the exploration of concept and term is impossible without the stratigraphic "variability".

\section{Conclusions}

The conceptual system and working methods of sequence stratigraphy are confused and inconsistent; it is not yet mature to confirm a formal sequence stratigraphic unit in stratigraphic code and guideline. There are always a number of obstacles and difficulties in the progress of standardization of sequence stratigraphy, and at the same time, the necessity and urgency of standardization is needed. Based on the transgressive-regressive process of sequence formation and the amendment of the incongruous Exxon sequence stratigraphic conceptual system, the cognition of the four processes (transgression, lowstand, highstand normal regression, forced regression) of sequence formation is summarized, and also it is an important step towards the standardization of sequence stratigraphy. Based on the sedimentary units possessing the respective characteristics of low- and high-accommodation sediments in fluvial sediments; the concept of "low- and high-accommodation system tract" is summarized, which is also another successful attempt of sequence stratigraphy standardization. Earlier intelligent achievements of scientists are an important foundation for the standardization of sequence stratigraphy, which provide more ideas and approaches for the further development of sequence stratigraphy and thus have a profound scientific connotation and acceptation.

\section{References}

1. Payton C(1977) Seismic stratigraphy: applications to hydrocarbon exploration. AAPG Memoir, 26: 1516.

2. Brown L F, Fisher W L (1977) Seismic stratigraphic interpretation of depositional systems: examples from Brazilian rift and pull apart basins. In: Payton C E (ed)Seismic Stratigraphy-Applications to Hydrocarbon Exploration. American Association of Petroleum Geologists Memoir, 26: 213-248.

3. Vail P R (1987) Seismic stratigraphy interpretation using sequence stratigraphy, partI, seismic stratigraphy interpretation procedure. In: A W Bally (ed.). Atlas of seismic stratigraphy. AAPG Studies in Geology, 27:1-10.
4. Van Wagoner J C, Mitchum R M, Posamentier H W, et al (1987) Seismic stratigraphy interpretation suing sequence stratigraphy, part2, key definitions of sequence stratigraphy. In: A W Bally (ed.). Atlas of seismic stratigraphy. AAPG Studies in Geology, 27:11-14.

5. Mei Mingxiang(2010) Correlation of sequence boundaries according to discerning between normal and forced regressions -The first advance in sequence stratigraphy. Journal of Palaeogeography, 12(5): 549-564.

6. Mei Mingxiang(2011) From vertical stacking pattern of cycles to discerning and division of sequences: The third advance in sequence stratigraphy. Journal of Palaeogeography, 13(1):3754.

7. Wu Heyuan (2011) Review of sequence stratigraphy: diversification of models. Geological Science and Technology Information, 30(6): 60-65.

8. Galloway W E(1989) Genetic stratigraphic sequences in basin analysis:I. Architecture and genesis of flooding-surface bounded depositional units. AAPG Bulletin, 73: 125-142.

9. Embry A F, Johannessen E P(1992) T-R sequence stratigraphy, facies analysis and reservoir distribution in the uppermost Triassic- lower Jurassic succession, western SverdrupBasin, Arctic Canada. In: Vorren T, Bergsager E, Dahl-Stamnes O A, et al. (eds.). Arctic Geology and Petroleum Potential. NPF Special Publication, 2:121 - 46.

10. Embry A F(1993) Transgressive-regressive (T-R) sequence analysis of the Jurassic succession of the SverdrupBasin , Canadian Arctic Archipelago, Canadian Journal of Earth Sciences, 30: 301-320.

11. Goldhammer R K, Dunn P A and Hardie L A (1990) Depositional cycles, composite sea-level changes, cycle stacking patterns, and the hierarchy of stratigraphic forcing. Geological Society America Bulletin. 102(5): 535-562.

12. Mei Mingxiang (2010) Research on forming mechanism of long-term sequences - the second advance in sequence stratigraphy. Journal of Palaeogeography, 12(6): 711-728.

13. Li Shaohu (2012) About sequence boundary. Earth Science Frontiers, 19(1): 20-31.

14. Deng Hongwen, Wang Hongliang, NingNing. (2000) Sediment volume partition principle: theory basins for high-resolution sequence stratigraphy. Earth Science Frontiers (ChinaUniversity of Geosciences, Beijing). 7(4):305-313.

15. Ling Changsong, Zhang Yanmei, Liu Jingyan, Pang Baochen(2000) High resolution sequence stratigraphy and reservoir prediction. Earth Science Frontiers (ChinaUniversity of Geosciences, Beijing). 7(3):111-117.

16. Vail $\mathrm{P} \quad \mathrm{R}$, Mitchum Jr R $\mathrm{M}$, ThompsonIII(1977)Seismic stratigraphy and global changes of sea level part 3: Relative changes of sea 
level from coastal onlap. In: Payton C E (ed.) Seismic Stratigraphy! Applications to Hydrocarbon Exploration. AAPG Memoir, 26: 63-81.

17. Haq B U, Hardenbol J, Vail P R(1987) Chronology of fluctuating sea levels since the Triassic (250 million years ago to present). Science, 235(4793):1156-1167.

18. Hallam A (1998) Interpreting sea level. In: Doyle P, Bennett M R (eds.) Unlocking the Stratigraphical Record; advance in modern stratigraphy. Chichester, John Wiley \& Sons, p:421-439.

19. Emery D, Myers K(1997) Sequence Stratigraphy. London: Black-well, p: 1-297.

20. Hunt D, Tucker M E (1992) Stranded parasequences and the forced regressive wedge systems tract: deposition during base-level fall. Sedimentary Geology, 81: 1-9.

21. Posamentier H W, Allen G P (1999) Siliciclastic Sequence Stratigraphy-Concepts and Applications. SEPM Concepts in Sedimentology and Paleontology, $\mathrm{p}: 1-210$.

22. Jervey M(1992) Siliciclastic sequence development in foreland basins, with examples from the western Canada foreland basin. In: Macqueen R, Leckie D (eds.)Foreland basins and fold belts. AAPG memoir, 55: 47-80.

23. Helland-Hansen W, GjelbergJ(1994) Conceptual basis and variability in sequence stratigraphy: A different perspective. Sedimentary Geology, 92: 3152.

24. Helland-Hansen W (1995) Sequence stratigraphy theory: remarks and recommendations. In: R J Steel, $\mathrm{V}$ Felt, E EJohannessen and C Mathieu (Eds) Sequence Stratigraphy on the Northwest European Margin. Norwegian Petroleum Society (NPF), Special Publication 5. Elsevier, Amsterdam, pp. 1321.

25. Helland-Hansen W, Hampsonw G J(2009) Trajectory analysis: Concepts and applications. Basin Research, 21:454-483.

26. Henriksen S, Hampson G J, Helland-Hansen W, et al (2009) Shelf edge and shoreline trajectories: A dynamic approach to stratigraphic analysis. Basin Research, 21:445-453.

27. Posamentier H W, Morris W R (2000) Aspects of the stratal architecture of forced regressive deposits. In: Hunt D, Gawthorpe R L (eds) Sedimentary Responses to Forced Regressions. Geological Society of London Special Publication, 172:19-46.

28. Catuneanu O (2002) Sequence stratigraphy of clastic systems: concepts, merits, and pitfalls. Journal of African Earth Sciences, 35:1-43

29. Catuneanu O, Martins-Neto M A, Eriksson P G (2005) Precambrian sequence stratigraphy. Sedimentary Geology, 176:67-95.

30. Catuneanu O, Martins-Neto M A, Eriksson P G (2012) Sequence Stratigraphic Framework and
Application to the Precambrian. Marine \& Petroleum Geology, 33:26-33.

31. Posamentier H W, Allen G P, James D P, et al (1992) Forced regressions in a sequence stratigraphic framework: concepts, examples and exploration significance. American Association of Petroleum Geologists Bulletin, 76: 1687-1709.

32. Johnson J G, Klapper G. and Sandberg C A (1985) Devonian eustatic fluctuations in Euramerica. Geol. Soc. Am. Bull., 96: 567-587.

33. Frazier D E (1974) Depositional episodes: their relationship to the Quaternary stratigraphic framework in the northwestern portion of the Gulf basin. University of Texas at Austin, Bureau of Economic Geology Geological Circular. 74-1:1-26.

34. Posamentier H W, Jervey M T, Vail PR (1988) Eustatic controls on clastic deposition Iconceptual framework. In: Wilgus C K, Hastings BS, Kendall C G St C, et al. (eds.) Sea level changesAn Integrated approach. SEPM Special Publication, 42:109-124.

35. Embry A F (1995) Sequence boundaries and sequence hierarchies: Problems and proposals. In: Steel R J, Felt V L, Johannessen E P, et al.(eds) Sequence Stratigraphy on the Northwest European Margin Norwegian Petroleum Society Special Publication, 5:1-11.

36. Walker R G (1990)Facies modeling and sequence stratigraphy. J. Sediment. Petrol., 60:777-786.

37. Walker R.G (1992) Facies, facies models and modern stratigraphic concepts. In: R.G. Walker and N.P. James (eds.)Facies Models, Response to SeaLevel Change. Geological Association of Canada, pp:1-14.

38. Catuneanu O, Abreu V, Bhattacharya $\mathrm{J} \mathrm{P}$, et al (2009) Reply to the comments of W. HellandHansen on "Towards the standardization of sequence stratigraphy" by Catuneanu et al. EarthScience Reviews, 94: 98-100.

39. Catuneanu O (2006) Principles of Sequence Stratigraphy . Amsterdam: Elsevier, 1-375.

40. Miall A D(1996) The geology of fluvial deposits. Berlin: Springer.

41. Shanley K W, McCabe P J (1994) Perspectives on the sequence stratigraphy of continental strata. AAPG Bulletin, 78(4):544-568.

42. Wright V P, Marriott S B (1993) The sequence stratigraphy of fluvial depositional systems: The role of floodplain sediment storage. Sedimentary Geology, 86(3/4): 203-210.

43. Zhang Zhouliang(1996) Fluvial sequence stratigraphy and river types. Geological Review, 42(Sup):188-193.

44. Posamentier H W, Allen G P (2000) Siliciclastic sequence stratigraphy: Concepts and applications. SPEM Series, Tulsa: Society for Sedimentary Geology. p:1-204. 
45. Zhang Zhouliang, Sun Keqin, Yin Jarun(1997) Sedimentology and sequence stratigraphy of the Shanxi Formation (Lower Permian) in the northwestern Ordos Basin, China: An alternative sequence model for fluvial strata. Sedimentary Geology, 112(1):123-136.

46. Wu Yinye, Zhang Tianshu, Zhang Zhijie, Cui Huajuan(2010) Types and characteristics of depositional systems tract and its petroleum geological significance. Journal of Palaeogeography, 12(1): 69-81.

47. Olsen T, Steel R, Hogseth K, et al (1995) Sequential architecture in a fluvial succession: Sequence stratigraphy in the upper Cretaceous Mesaverde Group, PriceCanyon. Utah. Journal of Sedimentary Research, 65(2):265-280.

48. DahleK, Flesja K, Talbot M R, et al (1997) Correlation of fluvial deposits by the use of Sm-Nd isotope analysis and mapping of sedimentary architecture in the Escamilla Formation (Ainsa Basin, Spain) and the Statfjord Formation (Norwegian North Sea). In: Abstracts,Six International Conference on Fluvial Sedimentology, Cape Town. p:47-48.

49. Fanti F, Catuneanu O (2010) Fluvial sequence stratigraphy: The Wapiti Formation, west-central Alberta, Canada. Journal of Sedimentary Research, 80(4): 320-338.

50. Lin Xiaobing, Tian Jingchun, Liu Liping, Yang Yingtao, Fu Ju, Wu Ling (2011) Research on fine sandbody correlation method under the double constraints of isochronous framework and seismic inversion. Journal of ChinaUniversity of Mining \&Technology, 40(3): 417-423.

51. Zhu Rukai, Zhao Xia, Liu Liuhong, Wang Xuesong, Zhang Nai, GuoHongli, Song Lihong (2009) Depositional system and favorable reservoir distribution of Xujiahe formation in Sichuan basin. Petroleum Exploration and Development, 36(1):4655.

52. Zhu Rukai, Bai Bin, Liu Liuhong, Su Ling, Gao Zhiyong, Luo Zhong (2011) Research on standardization of continental sequence stratigraphy and palaeogeography : A case study from the Upper Triassic Xujiahe Formation in Sichuan Basin. Earth Science Frontiers, 18(4):131-143.

53. Mei Mingxiang, Liu Shaofeng (2013) Discussion of alluvial architecture for the Upper Triassic Xujiahe Formation in terms of sedimentological impact of terrestrial vegetation on fluvial sedimentation: A case study at Pu'an section in Yongchuan of Chongqing. Journal of Palaeogeography, 15(2): 143154.

54. Embry A F. and Podruski J A (1988) Third-order depositional sequences of the Mesozoic succession of SverdrupBasin. In: D.P. James and D.A. Leckie (eds.) Sequences, Stratigraphy, Sedimentology: Surface and Subsurface. Can. Soc. Pet. Geol., Mem., 15: $73-84$.
55. Schlager W (1993) Accommodation and supply--a dual control on stratigraphic sequences. In: S. Cloetingh, W. Sassi, F. Horvath and C. Puigdefabregas(eds.) Basin Analysis and Dynamics of Sedimentary Basin Evolution. Sediment. Geol., 86:111-136 